\title{
New green roof and green wall systems for implementation in the coverings
}

\author{
Elena Korol $^{1}$, Natalia Shushunova ${ }^{1 *}$ and Stepan Rerikh $^{2}$ \\ ${ }^{1}$ Moscow State University of Civil Engineering, 129337, 26, Yaroslavskoye Shosse, Moscow, Russia \\ ${ }^{2}$ Brno University of Technology, Techicka 2851/15, 61600, Brno, Czech Republic
}

\begin{abstract}
In this article, the approaches to the application of evaluation systems for green buildings to the processes of modeling and designing green infrastructure in the development of the management mechanism of the urban environment, the problems of using green roof technologies are reviewed. The implementation of new green roof and green wall systems requires the accumulation of parametric data for variability in the selection of rational decisions. This study presents new green roof and green wall technologies and describes the main device advantages compared to existing coverings. The study applied the methods of comparative analysis of various options for roofing systems, including landscaping, based on the principles of labor and time savings. The comparison is made of the various indicators of the labor intensity of the covering device, using methods of structural-functional modeling. On the graphical models the identification of the structural separate layers of the roof structure is shown, which clearly represents the variable model according to various indicators of labor intensity. This research presents the new green roof and green wall technologies for implementation in the coverings and describes the main device advantages compared to existing coverings, which designed for simple cost-effective installation and modern urban design flexibility.
\end{abstract}

\section{Introduction}

New construction technologies, which form the urban environment with a green roof and green wall systems, influencing the global warming effect, are growing rapidly in many developed countries, the principles of moral responsibility of green buildings create a favorable environment for the health and well-being of the population. However, it should be noted, that there are not so many studies of technological parameters in arranging green roofing, such studies are mainly related to identifying the ecological potential of green roofing, considering their noise absorbing characteristics and factors influencing the microclimate near buildings. The method, tested under controlled laboratory conditions and in-situ on a real green wall is an alternative to the ISO354-2003 and CEN/TS 17935:2016 standard methods to measure acoustic absorption of green wall materials [7]. Applied research in the Laboratory for the Restoration and Maintenance of the University

*Corresponding author: nshushun@gmail.com 
of Naples Federico II in conjunction with the Institute of Composite and Biomedical Materials - IMCB - National Research Council of Italy - CNR explores the potential of Hypucem's patented hybrid foam as a clean technology for restoring flat roofs in reinforced concrete buildings [8]. Environmental and economic model life cycle of buildings, the model that allows at the design stage to determine and evaluate the energy efficiency of buildings [4-6], which based on the concept of the sustainable development in Green Building, also were considered [9-11].

This research presents the new green roof and green wall technologies for implementation in the coverings and describes the main device advantages compared to existing coverings. Green covering of the building contributes to the positive role of buildings: reduces the negative impact of buildings on the environment, and also supports the national economy for the sustainable development [12].

\section{Methodology}

The study applied the methods of comparative analysis of various options for roofing systems, including landscaping, based on the principles of labor and time savings. The comparison is made of the various indicators of the labor intensity of the covering device, using methods of structural-functional modeling. The study also provides an analysis of the structural and technological systems for constructing covering on the green walls.

Consider the different types of the green roofing and the green walls covering systems. Basically, the covering (roof) includes a roof, a base under the roof, thermal insulation, a roofing waterproofing layer, a slope-forming layer and a supporting structure (reinforced concrete slabs, corrugated flooring, etc.). The green roof systems have a series of components that must be installed in layers on a roof surface (Figure 1):

I. The labor intensity of the device of bearing structure $\left(\mathrm{Q}_{\mathrm{bs}}\right)$;

II. The labor intensity of the device of operated coating (Level 8-10);

III. The labor intensity of the device of underlay structure (Level 1-7, $\mathrm{Q}_{\mathrm{ml}}$ );

IV. The total labor intensity of the device of a multilayer roof structure $\left(\mathrm{Q}_{\mathrm{tot}}\right)$. 


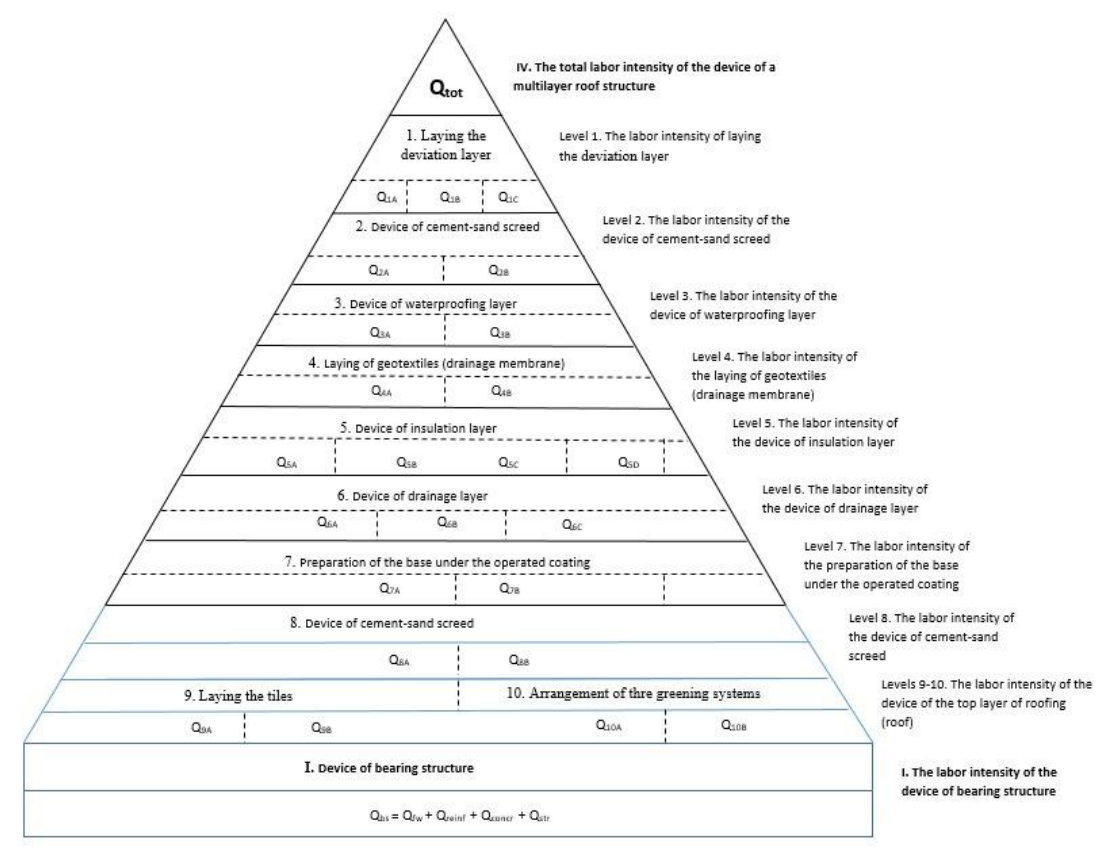

Fig. 1. The pyramid of hierarchies of indicators of the labor intensity of the device for multi-layer construction of the green covering systems

Various types of coatings planting systems like roofing and green wall coverings include coverings without planting systems (traditional type), all-over covering systems with greening structures (non-modular type) and modular greening systems for covering, which shown on Figure 2.

Green wall impacts inside and outside buildings were experimented in the study to obtain the thermal effects of green facades. Measurements were performed in La Rochelle city in France.

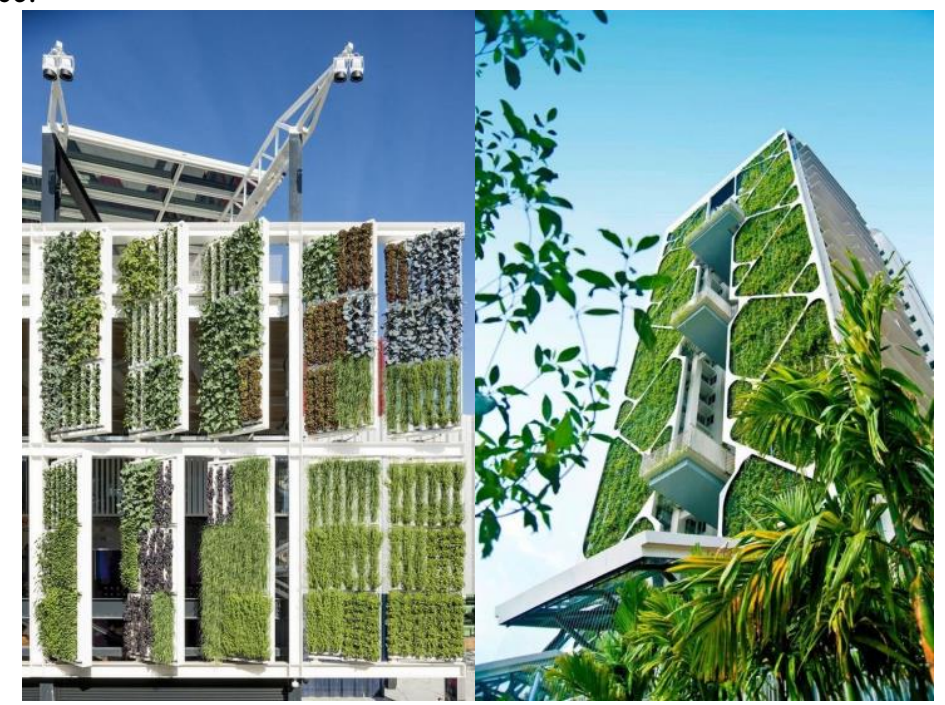

Fig. 2. The various types of the green covering systems 
Traditional built-in green roofs were first developed in Europe and are still widely adopted in the market. These green roofs are more complex, permanent and expensive than modular systems. They have certain limitations, including complex logistic installation, overweight (about 180-450 kg / m2), long installation time and difficulty of maintenance. Once a built-in green roof is put in place, it cannot be changed easily.

The first Modular Green Roof System was based on the polystyrene in 1978, the boxes were very lightweight and easy to install [16]. Actually, they fitted into each other to create different heights and different planting depths. Unfortunately, any polystyrene as a limited lifespan when exposed to UV or biological activity and so many of these roof gardens had problems after 5-10 years. Further, many of the plants rooted out of the boxes (drainage holes) and penetrated the waterproofing.

Our Modular Green Roof System and Modular Green Wall System are designed for simple cost-effective installation and design flexibility. It was developed with channels to allow air flow through the system. This helps mitigate wind uplift and supplies oxygen to plant roots (Figure 3). The channels also accommodate irrigation supply lines for all types of irrigation systems, either during installation or post-installation. Deeper reservoirs help the system maximize storm water retention, which also keeps water available for plants between rainfall events. This system is perfect for extensive and semi-intensive vegetated green roof designs $[2,17]$.

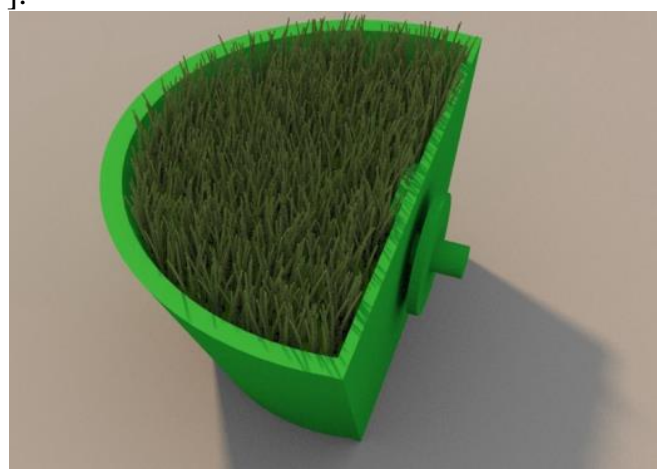

Fig. 3. The module of green covering systems

The types of plants suitable for this system are those native mainly to locations with dry and semi-dry conditions or with rocky outcrops, such as an Alpine environment. The most common types of extensive plants would include sedum, wildflowers and some grasses [1315]. Brown or biodiverse roofs are also suitable to be used with the extensive modules. Modeling of green walls and green roofs as an Urban Heat Island Adaptation Strategy were shown in the study, which describes features of the tropical climate [18].

\section{Results}

On the graphical model, shown in figure 1, the identification of the structural separate layers of the roof structure, which clearly represents the variable model according to various indicators of labor intensity, is convenient.

Analysis of the indicators of the labor intensity of the device of the various types of coatings planting systems: coverings without planting systems (traditional type), all-over covering systems with greening structures (non-modular type) and modular greening systems for covering, showed, that total labor intensity Qtot of device of the traditional type is compiled 98,4 labour-hours (100\%), Qtot of device of the all-over covering systems with greening structures (non-modular type) is compiled 107,9 labour-hours (110\%), Qtot of device of the modular greening systems for covering is compiled 79,3 labour-hours $(81 \%)$, 
of this amount labor intensity of device of the multilayer structures Qml is 50,2 labourhours, that is less by $48 \%$ than $\mathrm{Qml}$ of the all-over covering systems (Figure 4).

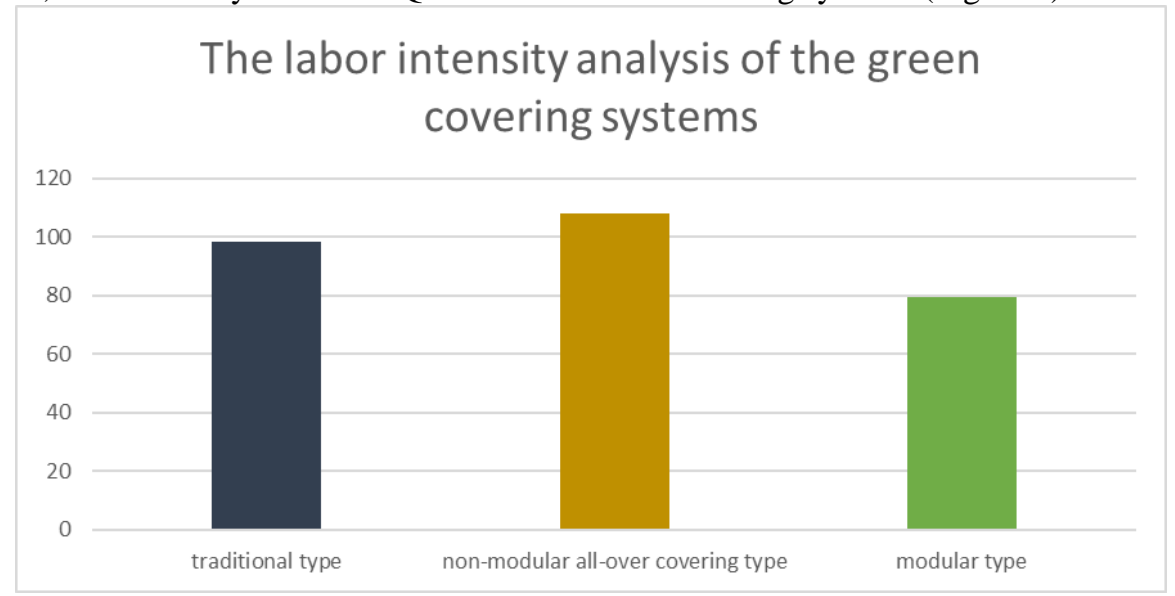

Fig. 4. The analysis of the indicators of the labor intensity of the device of the green covering systems

Thus, by varying the design of certain layers of a multi-layer structure when constructing modular systems, we achieve a reduction in the total labor intensity of the device of greening systems by $19-25 \%$.

As well as providing all the usual benefits a green roof can bring: to reduce air and noise pollution and helps to cool the surrounding temperature as well. MGRS have a positive impact on the environment in that; they help reduce carbon dioxide concentration as grass and other vegetation aid in air purification. Air around most urban centers is mostly toxic because very few trees or grass are present.

However, having some vegetation on every apartment's rooftop can help deal with the toxic air. Another key benefit of using a green roof is that, it helps conserve heat by reducing heat loss during winter, and reducing heat absorption into the house during hot weather and summer. These roofs have also shown the ability to reduce storm water runoff. Storm water is often destructive as it carries away anything in its way, as well as damage waterways. These roofs however retain water reducing its speed and impact on these waterways.

Conventional roofs generate more heat especially when the house or a substance is on fire as compared to green roofs. The reason is that a living roof can withstand intense heat thus making it possible to contain house fires. In addition to this, the installation of a green roofing system can reduce sound from the outside by as much as a whopping 40 decibels [9]. This makes your home or the office quieter especially in noisy neighborhoods and near airports. There are more additional benefits. Our system is modular, roof surfaces are always accessible for maintenance, additions and changes. Should such an occasion occur, our modules are simply removed, then put back in place when the work is completed, without disturbing the growth medium or the plants [3].

\section{Conclusions}

Thus, as a result of this study, we conclude that the design of modular greening systems for covering is much more efficient in terms of labor intensity than the all-over covering systems with greening structures and traditional types of coverings. At present, there is no regulatory and technical framework that regulates the development of organizational and technological solutions in Russia for roofing and building facade coatings, using greening 
systems. The introduction of modern construction technologies requires the development of national organizational-technological and BIM-modeling tools for their use in design and organizational-technological documentation in order to reduce the time, laboriousness and improve the quality of construction [1]. While in the UK, Singapore, Finland and the United States already exist national BIM-standards. For adaption to the Russian conditions in order to develop the principles of organizational and technological modeling, the optimal solution would be to use the Finnish standard for modeling.

The result of this study can be used in the development of modern BIM-solutions for building roofing and facade systems of buildings in order to select the optimal organizational and technological solutions for the construction of buildings.

This work was financially supported by Ministry of Science and Higher Education of the Russian Federation (\#NSh-3492.2018.8).

\section{References}

1. E.B. Sugak, On some of the official duties of security specialists Labor in Germany. Man and work, 10, pp.48-51. (2013)

2. E. Korol, N. Shushunova, Research and Development for the International Standardization of Green Roof Systems, Procedia Engineering, 153, pp. 287-291 (2016) https://doi.org/10.1016/j.proeng.2016.08.117

3. S. Korol, N. Shushunova and T. Shushunova, Innovation technologies in Green Roof systems // Matec Web of Conferences, Volume 193, 04009. (2018) https://doi.org/10.1051/matecconf/201819304009

4. A. Volkov, L.V. Sukneva, BIM-Technology in Tasks of the Designing Complex Systems of Alternative Energy Supply, Procedia Engineering, 91, pp. 377-380 (2014) https://doi.org/10.1016/j.proeng.2014.12.078

5. Korol O.A. Issledovaniya $\mathrm{i}$ naukoyemkiye razrabotki $\mathrm{v}$ oblasti energoeffektivnogo stroitel'nogo proizvodstva [Research and knowledge-intensive developments in the field of energy-efficient construction production] Stroitel'nyye materialy [Construction Materials]. no 6. pp. 13-15. (In Russian) (2015)

6. V.G. Borkovskaya, Complex models of active control systems at the modern developing enterprises. Advanced Materials Research, Advanced Materials Research, Vol. 945-949, Chapter 22, Pages 3012-3015. (2014) Manufacturing Management and Engineering Management. June 2014. DOI: 10.4028/www.scientific.net/AMR.945949.3012

7. A. Romanova, K. Horoshenkov, A. Hurrell, An application of a parametric transducer to measure acoustic absorption of a living green wall, Applied Acoustics, Vol. 145, Pp. 8997 (2019) https://doi.org/10.1016/j.apacoust.2018.09.020

8. S. Viola, Green roofs for built environment recovery: technological transitions, Journal of Cleaner Production, Vol.153, pp. 592-599 (2017) https://doi.org/10.1016/j.jclepro.2016.03.052

9. E. Korol, N. Shushunova, O. Feoktistova, T. Shushunova and O. Rubtsov, Technical and economical factors in green roof using to reduce the aircraft noise, MATEC Web of Conferences, 170, 01081 (2018) https://doi.org/10.1051/matecconf/201817001081

10. V.G. Borkovskaya, Environmental and Economic Model Life Cycle of Buildings Based on the Concept of "Green Building", Materials Science and Mechanical Engineering, pp. 287-290 (2013) DOI: 10.4028/www.scientific.net/AMM.467.287

11. V.G. Borkovskaya, Post bifurcations of the concept of the sustainable development in construction business and education. Advanced Materials Research, Vol. 860-863, 
chapter 26, Pp. 3009-3012, (2013) DOI:10.4028/www.scientific.net/AMR.860863.3009

12. R. Roe, W. Bardenwerper, V. Borkovskaya, Using a Case Study Interactively to teach Sustainability Risk Management, MATEC Web of Conferences, Vol. 251, 06028 (2018). DOI: https://doi.org/10.1051/matecconf/201825106028

13. Naomi J. Paull, Peter J. Irga, Fraser R. Torpy, Active green wall plant health tolerance to diesel smoke exposure, Environmental Pollution, Vol. 240, Pp. 448-456 (2018) https://doi.org/10.1016/j.envpol.2018.05.004

14. A. Medl, R. Stangl, S.B. Kikuta, F. Florineth, Vegetation establishment on 'Green Walls': Integrating shotcrete walls from road construction into the landscape, Urban Forestry \& Urban Greening, Vol. 25, July 2017, Pp. 26-35 (2017) https://doi.org/10.1016/j.ufug.2017.04.011

15. R. Djedjig, R. Belarbi, E. Bozonnet, Green wall impacts inside and outside buildings: experimental study, Energy Procedia, Vol.139, Pp. 578-583, (2017) https://doi.org/10.1016/j.egypro.2017.11.256

16. J. Magill, K. Midden, J. Groninger and M.Therrell, A History and Definition of Green Roof Technology with Recommendations for Future Research, research papers, paper 91, (2011) http://opensiuc.lib.siu.edu/gs_rp/91

17. On-line: https://www.grooflab.com/home-4-de

18. H. M. P. I. K. Herath, R.U. Halwatura, G.Y. Jayasinghe, Modeling a Tropical Urban Context with Green Walls and Green Roofs as an Urban Heat Island Adaptation Strategy, Procedia Engineering, Vol. 212, Pp. 691-698 (2018) https://doi.org/10.1016/j.proeng.2018.01.089 